\title{
PENGARUH KEPUASAN PELANGGAN TERHADAP LOYALITAS MEREK PADA KARTU PRABAYAR SIMPATI TELKOMSEL
}

(Studi Kasus Pada Pengguna Kartu Prabayar SimPATI Telkomsel di Lingkungan Mahasiswa Pendidikan Ekonomi Angkatan 2014 - 2017 FKIP

Universitas Jember)

\section{Lia Indah Wahyuni ${ }^{1}$, Sri Wahyuni ${ }^{1}$, Joko Widodo ${ }^{1}$}

${ }^{1}$ Program Studi Pendidikan Ekonomi, Fakultas Keguruan dan Ilmu Pendidikan, Universitas Jember e-mail: 140210301032@students.unej.ac.id

\begin{abstract}
Abstrak
Kepuasan pelanggan dalam aplikasinya bergantung pada loyalitas merek yang memiliki indikator seperti pilihan pertama, kesetiaan, berani membayar lebih. Semakin tinggi kepuasan pelanggan maka akan semakin baik loyalitas merek yang dimiliki pengguna kartu simPATI tersebut, artinya semakin pengguna kartu simPATI tersebut dapat menerima tarif, jaringan, layanan, kinerja operator dengan puas dan senang, maka pengguna kartu simPATI telah memiliki loyalitas terhadap merek simPATI. Pengguna simPATI didominasi oleh mahasiswa yang memiliki umur antara 22 tahun. Mahasiswa dengan rutinitasnya tidak bisa terlepas dari paket data dan kebanyakan dari mereka membutuhkan koneksi yang cepat untuk mendukung tugas/pekerjaan mereka sehingga menyebabkan mereka loyal terhadap kartu simPATI yang memiliki jaringan tercepat. Tujuan penelitian ini yaitu untuk mengetahui pengaruh yang signifikan kepuasan pelanggan terhadap loyalitas merek pada mahasiswa. Adapun penentuan sampel dalam penelitian ini menggunakan purposive area yakni mahasiswa Pendidikan Ekonomi, FKIP, Universitas Jember dengan jumlah responden 83 orang. Metode analisis data yang digunakan adalah analisis inferensial dengan menggunakan persamaan garis regresi linier sederhana. Hasil penelitian menunjukkan bahwa kepuasan pelanggan memiliki pengaruh yang signifikan terhadap loyalitas merek mahasiswa Pendidikan Ekonomi, FKIP, Universitas Jember. Hasil Uji F menunjukkan $\mathrm{F}_{\text {hitung }}=182,696>\mathrm{F}_{\text {tabel }}=3,957$ dengan tingkat signifikansi $0,000<a=0,05$ dengan persamaan regresi sederhana $\hat{Y}=3,867+0,770 X$. Hasil perhitungan koefisien determinasi $\left(\mathrm{R}^{2}\right)$ sebesar 0,697, hal ini menunjukkan bahwa besarnya persentase pengaruh kepuasan pelanggan terhadap loyalitas merek mahasiswa Pendidikan Ekonomi, FKIP, Universitas Jember sebesar 69,7\%.
\end{abstract}

Kata Kunci: Facebook, Perilaku konsumtif , Social media marketing

\section{PENDAHULUAN}

Penggunaan gadget seperti Smartphone, Tablet, Laptop tidak akan lengkap bila tidak didukung adanya fitur-fitur sosial media dan juga browsing atau menjelajah internet, oleh karena itu diperlukan kartu perdana yang sesuai dengan kebutuhan salah satunya adalah kartu perdana simPATI.

Tabel 1.1 Top Brand Simcard Prabayar Tahun 2018 Fase 1

\begin{tabular}{ccc}
\hline MEREK & TBI & TOP \\
\hline Simpati & $39.7 \%$ & TOP \\
IM3 & $14.4 \%$ & TOP \\
XL Prabayar & $12.7 \%$ & TOP \\
Tri '3' & $11.4 \%$ & \\
Kartu AS & $9.4 \%$ & \\
Axis & $8.3 \%$ & \\
\hline
\end{tabular}

Sumber : topbrand-award.com

Berdasarkan data yang diperoleh dari survey yang dilakukan oleh top brand simcard award tahun 2018 Fase 1 menunjukkan bahwa merek simPATI menduduki peringkat tertinggi. SimPATI memperoleh peringkat teratas mencerminkan adanya kepercayaan para pengguna ponsel terhadap produk dan layanan simPATI, sehingga dapat dikatakan bahwa merek simPATI merupakan merek simcard prabayar yang saat ini paling banyak diminati oleh masyarakat Indonesia.

SimPATI merupakan salah satu produk dari Telkomsel. Merek simPATI yang sudah melekat di 
dalam benak masyarakat hal itu menjadi daya tarik tersendiri bagi konsumen sehingga mereka lebih memilih menggunakan simPATI. Meskipun harga paket internet simPATI 4G LTE masih relatif mahal, bisa dikatakan jumlah penggunanya terus mengalami kenaikan. Harus diakui bahwa Telkomsel memiliki paket simPATI terbaik dengan jaringan 4G LTE terkuat yang dapat dinikmati para pengguna disebagian besar pulau Jawa, Sumatera, Kalimantan, Sulawesi, dan Bali (www.pikiran-rakyat.com).

Hal yang tidak mudah bagi simPATI untuk mempertahankan posisi yang telah dimiliki simPATI di tengah persaingan bisnis jasa telekomunikasi selular GSM yang semakin kompetitif dan ketat. Kondisi ini mengharuskan simPATI membuat strategi untuk mempertahankan eksistensi dan menjadi market leader. Salah satu strategi yang dapat dilakukan adalah menciptakan loyalitas merek pada konsumen.

Menciptakan loyalitas merek bukanlah tugas mudah, mengingat perubahan-perubahan dapat terjadi setiap saat, baik perubahan pada diri konsumen, seperti selera, maupun persaingan kompetitor lain seperti bermunculan promo-promo dari para pesaing simPATI baik dari XL, Indosat maupun simcard lainnya yang memberikan harga paket internet, sms dan telepon lebih murah, kecepatan akses internet dan bonus yang diberikan merupakan suatu permasalahan bagi simPATI karena akan mempengaruhi keputusan konsumen untuk terus berlangganan kartu perdana simPATI.

Seorang pelanggan yang sangat loyal kepada suatu merek tidak akan dengan mudah memindahkan pembeliannnya ke merek lain, apapun yang terjadi pada merek tersebut. Pelanggan yang loyal pada umumnya akan melanjutkan pembelian merek tersebut walaupun dihadapkan pada banyak alternatif merek produk pesaing yang menawarkan karakteristik produk yang lebih unggul dipandang dari berbagai sudut atributnya (Durianto, 2001:126). Oleh karena itu, mempertahankan loyalitas konsumen pada suatu merek merupakan hal penting yang harus dilakukan oleh perusahaan. Loyalitas merek tidak terjadi tanpa sebab, banyak sebab yang membuat konsumen loyal terhadap merek salah satunya adalah kepuasan konsumen. Untuk mendapatkan konsumen yang loyal kebutuhan konsumen perlu dipuaskan secara konsisten merek tertentu dimasa yang akan datang dari waktu ke waktu.

Sebagai market leader kartu seluler di Indonesia, simPATI telah lekat dihati pelanggan. Hal ini dikarenakan simPATI memiliki keunggulan seperti, jangkauan yang luas, GraPARI yang tersebar dimana-mana, kualitas tinggi, harga yang kompetitif, fleksibel dan transparan, pelayanan terhadap pelanggan yang handal. Telkomsel juga berhasil menggaet berbagai penghargaan diantaranya, pengalaman pemasaran terbaik dan pengalaman The Best Experiential Marketing and customer experience. (Sari, 2012:122)

Mahasiswa merupakan salah satu pangsa pasar yang potensial bagi perusahaan telekomunikasi di Indonesia. Tidak menutup kemungkinan bagi simPATI untuk meraih pasar anak muda yang menginginkan operator selular dengan kualitas layanan yang baik dan juga merek berkualitas. Para pesaing simPATI sedang gencar-gencar nya menetapkan harga dibawah simPATI sehingga membuat persaingan semakin ketat, tetapi tidak menutup kemungkinan mahasiswa tetap memilih merek produk dengan kualitas layanan yang baik, meskipun dengan harga yang sedikit mahal.

Peneliti melakukan pra survey di lingkungan mahasiswa karena dirasa sudah dewasa (>17 tahun) sehingga dapat memberikan jawaban pada kuesioner secara objektif dan rasional, peneliti meneliti khususnya mahasiswa Pendidikan Ekonomi FKIP Universitas Jember dan mendapatkan hasil yang menunjukkan banyak mahasiswa yang menggunakan merek kartu prabayar simPATI sehingga peneliti merasa tertarik untuk melakukan penelitian pada mahasiswa Pendidikan Ekonomi FKIP Universitas Jember.

Berdasarkan latar belakang diatas, maka penulis ingin melakukan penelitian dengan judul "Pengaruh Kepuasan Pelanggan Terhadap Loyalitas Merek Pada Kartu Prabayar simPATI Telkomsel (Studi kasus pada Pengguna Kartu Prabayar simPATI Telkomsel di Lingkungan Mahasiswa Pendidikan Ekonomi Angkatan 2014 - 2017 Ekonomi Fakultas Keguruan dan Ilmu Pendidikan Universitas Jember)”.

\section{METODE}

Penelitian ini dilakukan dengan metode kuantitatif menggunakan analisis regresi linier sederhana. Adapun metode penentuan lokasi penelitian menggunakan purposive area dan penentuan sampel menggunakan purposive sampling, yakni mahasiswa Program Studi Pendidikan Ekonomi, FKIP, Universitas Jember dengan jumlah responden 83 orang. Metode pengumpulan data menggunakan angket, wawancara, observasi, 
dokumentasi dengan skala likert, dan wawancara terstruktur. Analisis data yang digunakan adalah varian garis regresi, Uji F, dan koefisien determinasi, untuk memudahkan perhitungan analisis data maka peneliti menggunakan bantuan program SPSS 22.0 for windows.

\section{HASIL DAN PEMBAHASAN}

\section{Hasil Penelitian}

Hasil perhitungan analisis regresi linier sederhana dengan menggunakan program SPSS 22.0 for windows adalah sebagai berikut:

Tabel 1. Hasil analisis regresi linier sederhana

\begin{tabular}{|c|c|c|c|c|c|c|}
\hline \multirow[b]{2}{*}{ Model } & & \multicolumn{2}{|c|}{$\begin{array}{c}\text { Unstandardized } \\
\text { Coefficients }\end{array}$} & \multirow{2}{*}{\begin{tabular}{|l|}
$\begin{array}{r}\text { Standardized } \\
\text { Coefficients }\end{array}$ \\
Beta
\end{tabular}} & \multirow[b]{2}{*}{$\mathrm{T}$} & \multirow[b]{2}{*}{ Sig. } \\
\hline & & B & Std. Error & & & \\
\hline 1 & (Constant) & 3,867 & ,975 & & 3,964 &, 000 \\
\hline & $\begin{array}{l}\text { Kepuasan } \\
\text { Pelanggan }\end{array}$ &, 770 &, 057 &, 832 & 13,517 &, 000 \\
\hline
\end{tabular}

Berdasarkan data di atas, maka persamaan regresi sederhana yang diperoleh dalam penelitian ini adalah sebagai berikut:

$$
\mathrm{Y}=\mathbf{3 , 8 6 7 + 0 , 7 7 0 X + \varepsilon _ { i }}
$$

Adapun hasil perhitungan untuk analisis varian garis regresi adalah sebagai berikut:

Tabel 2. Hasil interpretasi model summary

\section{Model Summary ${ }^{b}$}

\begin{tabular}{|l|r|r|r|r|}
\hline Model & $\mathrm{R}$ & \multicolumn{1}{|c|}{ R Square } & Adjusted R Square & Std. Error of the Estimate \\
\hline 1 &, $832^{\mathrm{a}}$ &, 693 &, 689 & 2,141 \\
\hline
\end{tabular}

Berdasarkan hasil data yang didapatkan seperti yang terlihat pada tabel di atas, maka diketahui besarnya nilai koefisien korelasi adalah 0,832. Koefisien korelasi sebesar 0,832 tersebut menunjukkan bahwa hubungan antara variabel (X) kepuasan pelanggan terhadap variabel (Y) loyalitas merek mahasiswa Pendidikan Ekonomi, FKIP, Universitas Jember dikategorikan mempunyai hubungan yang sangat kuat.

Hasil $R$ Square seperti yang terlihat pada tabel 2 sebesar 0,697, sehingga hasil akhir setelah dimasukkan ke dalam rumus koefisien determinasi $\left(\mathrm{R}^{2}\right)$ adalah sebagai berikut: 
Hal ini menunjukkan bahwa besarnya persentase pengaruh kepuasan pelanggan terhadap loyalitas merek mahasiswa Pendidikan Ekonomi, FKIP, Universitas Jember sebesar 69,7\%. Adapun perhitungan dari Uji $\mathrm{F}$, diketahui nilai $\mathrm{F}_{\text {hitung }}$ sebagai berikut:

Tabel 3. Hasil uji F

ANOVA $^{b}$

\begin{tabular}{|ll|r|r|r|r|r|}
\hline Model & & Sum of Squares & Df & Mean Square & F & Sig. \\
\hline 1 & Regression & 837,321 & 1 & 837,321 & 182,696 &, $000^{\mathrm{a}}$ \\
& Residual & 371,234 & 81 & 4,583 & & \\
& Total & 1208,554 & 82 & & & \\
\hline
\end{tabular}

a. Predictors: (Constant), Kepuasan Pelanggan

b. Dependent Variable: Loyalitas Merek

Berdasarkan data di atas, diketahui bahwa nilai $\mathrm{F}_{\text {hitung }}=182,696$ lebih besar dari $\mathrm{F}_{\text {tabel }}=3,957$ dengan tingkat signifikansi 0,000 lebih kecil dari $a=0,05$. Hal ini menunjukkan bahwa variabel kepuasan pelanggan memiliki pengaruh yang signifikan terhadap loyalitas merek mahasiswa Pendidikan Ekonomi, FKIP, Universitas Jember.

\section{Pembahasan}

Hasil analisis inferensial dengan metode regresi linier sederhana yang diperoleh menunjukkan bahwa kepuasan pelanggan berpengaruh secara signifikan terhadap loyalitas merek kartu prabayar simPATI pada mahasiswa Pendidikan Ekonomi FKIP Universitas Jember sebesar 69,3\%. Hasil perolehan tersebut mengartikan bahwa tujuan peneliti tercapai karena hasil perhitungan analisis inferensial tersebut mampu menjawab rumusan masalah penelitian yaitu mengetahui adakah pengaruh yang signifikan kepuasan pelanggan terhadap loyalitas merek kartu prabayar simPATI pada mahasiswa Pendidikan Ekonomi FKIP Universitas Jember.

Kepuasan pelanggan memiliki beberapa indikator penting yang terdiri dari kesesuaian harapan, membeli kembali dan kesediaan merekomendasi yang menjadi tolok ukur pelanggan merasakan kepuasan terhadap produk atau jasa yang diperjual belikan. Produk simPATI menciptakan kepuasan pelanggan dengan memberikan kesesuaian harapan yang ditunjukkan dengan memberikan layanan secara baik yang bisa dinikmati oleh seluruh masyarakat, berdasarkan hasil wawancara dari salah satu responden mengungkapkan jika responden merasakan kepuasan menggunakan produk simPATI.

Saya memilih berlangganan simPATI karena sinyalnya bagus mbak, jarang mengalami trouble, saya pernah mencoba kartu lain tetapi lebih enak simPATI, selain itu koneksi internetnya cepat daripada operator-operator lain. (14-38, 22 th)

Kepuasan konsumen pada kartu simPATI ini didukung dengan kemudahan pelanggan untuk mendapatkan kartu simPATI dikarenakan kartu simPATI ada di seluruh Indonesia, pernyataan ini juga dijelaskan oleh Soim (2016) dalam jurnalnya yaitu saat ini diseluruh kota di Indonesia sangat mudah mencari produk simPATI baik pulsa ataupun kartu perdana simPATI, selain itu semua orang dapat dengan mudah mengakses semua layanan simPATI dengan aplikasi My Telkomsel dengan mudah, mulai dari cek tagihan, sisa pulsa, sisa kuota, informasi profil, dan fitur-fitur lainnya (jalantikus.com).

Faktor berikutnya yang mendorong pelanggan puas adalah pelanggan akan secara sukarela memberikan tanggapan atau rekomendasi yang baik meskipun tanpa ada yang memintanya, menurut Sari (2012) dalam jurnalnya menyatakan bahwa hal tersebut dikarenakan citra yang diberikan simPATI baik sehingga melekat dibenak pelanggan.

Responden yang loyal terhadap merek simPATI dapat dilihat dari beberapa faktor seperti pilihan pertama, kesetiaan, berani membayar lebih. Sebagai market leader kartu seluler di Indonesia, simPATI telah lekat dihati pelanggan. Hal ini dikarenakan simPATI memiliki keunggulan yang terus dipertahankan oleh simPATI sehingga responden selalu puas dan berniat akan terus loyal atau menggunakan kartu simPATI dalam jangka lama. Hal ini diketahui dari pemaparan hasil wawancara salah satu responden berikut: 
Kalau mau ganti kartu lain sepertinya tidak mbak, sudah nyaman menggunakan simPATI, karena saya lebih mementingkan kualitas, kan simPATI sudah dari dulu terkenal bagusnya. (16-81, 21 th).

Munculnya pesaing dari operator-operator lain tidak membuat simPATI menjadi kurang peminat sebab meskipun banyak promo-promo yang diberikan oleh para pesaingnya, hal ini dibuktikan dengan peroleh survey Top Brand Simcard Prabayar Tahun 2018 Fase 1 yang menunjukkan bahwa simPATI adalah merek yang terbanyak peminatnya kemudian diikuti oleh IM3, XL. (www.top brand-award.com), sehingga dapat diketahui bahwa layanan yang diberikan oleh simPATI tidak membuat kecewa pelanggan sehingga merek tidak ingin beralih ke merek lain. Seperti yang diungkapkan salah satu responden dalam wawancara menyatakan jika dia tidak terpikirkan untuk beralih ke operator lain.

Belum terpikirkan untuk beralih ke operator lain mbak, selama ini sudah kebiasaan menggunakan simPATI, pernah mencoba menggunakan kartu lain, hp saya dua simcard tapi tidak lama sudah tidak menggunakannya lagi dikarenakan masih lebih cepat koneksinya simPATI. (16-81, 21 th)

Harga yang ditawarkan oleh simPATI tergolong cukup mahal jika dibandingkan dengan harga yang ditawarkan oleh operator lain, walaupun ada keluh kesahnya dengan tarif yang diberikan simPATI tersebut tetapi mereka lebih menekankan kualitas dari produk simPATI tersebut, Selama kualitas komunikasi memuaskan/ tidak terputus-putus mereka akan tetap loyal terhadap simPATI karena harga yang dibayarkan sesuai dengan kualitas yang diberikan simPATI. Hal ini diketahui dari pemaparan hasil wawancara salah satu responden berikut:

Iya mbak, kartu simPATI itu tergolong mahal dibandingkan dengan operator lain tapi tidak apa-apa sinyalnya bagus, jaringan ada dimana-mana jadi tidak susah kalau misalnya lagi didesa-desa. (1438,20 th)

\section{PENUTUP}

Berdasarkan hasil penelitian dan pembahasan dapat disimpulkan bahwa ada pengaruh yang signifikan kepuasan pelanggan terhadap loyalitas merek kartu prabayar simPATI pada mahasiswa Pendidikan Ekonomi FKIP Universitas Jember. Besarnya persentase pengaruh kepuasan pelanggan terhadap loyalitas merek kartu prabayar simPATI pada mahasiswa Pendidikan Ekonomi FKIP Universitas Jember adalah 69,3\%.

Hasil penelitian yang telah dilakukan dapat diartikan bahwa semakin tinggi kepuasan pelanggan maka akan semakin baik loyalitas merek yang dimiliki pengguna kartu simPATI tersebut, sebaliknya semakin rendah kepuasan pelanggan maka akan semakin rendah loyalitas merek yang dimiliki pengguna simPATI tersebut. Artinya semakin pengguna kartu simPATI tersebut puas dengan jaringan simPATI, puas dengan layanan yang diberikan simPATI berupa mudah mendapatkan kartu simPATI dimana saja, secara sukarela memberikan tanggapan atau rekomendasi yang baik meskipun tanpa ada yang memintanya, selalu puas dan berniat akan terus loyal atau menggunakan kartu simPATI dalam jangka lama, tidak terpikirkan untuk beralih ke operator lain selain simPATI, tidak keberatan dengan sistem penarifan yang telah diatur oleh pihak simPATI, maka hal tersebut menunjukkan bahwa pelanggan semakin loyal terhadap simPATI.

Berdasarkan kesimpulan dari penelitian ini maka penulis memberikan saran kepada mahasiswa Pendidikan Ekonomi FKIP Universitas Jember, hendaknya lebih bijak menggunakan kartu prabayar disesuaikan dengan kebutuhan tidak hanya sekedar membeli saja, mengkonsumsi saja, agar tidak dikategorikan perilaku konsumtif yang berlebihan. Bagi peneliti lain, hendaknya mempertimbangkan sumbangan pengaruh variabel lain yang tidak dteliti dalam penelitian ini. Oleh karena itu diharapkan bagi peneliti yang akan melakukan penelitan lain serupa dengan penelitian ini mengambil variabel lain yang tidak diteliti seperti nilai, citra, kenyaman, garansi dll.

\section{DAFTAR PUSTAKA}

Durianto, D. Sugiarto, dan Tony S. 2001. Strategi Menaklukan Pasar Melalui Riset Ekuitas Dan Perilaku Merek. Jakarta: PT Gramedia Pustaka Utama.

Sari, M. K. 2012. Pengaruh "Experiential Providers" terhadap Loyalitas Konsumen Kartu Pra Bayar SimPATI TELKOMSEL. Jurnal Program Studi Pendidikan Ekonomi STKIP PGRI Sumatera Barat. 1 (1). 
Soim, F. M. 2016. Pengaruh Brand Image Terhadap Keputusan Pembelian (Studi Pada Pembeli Kartu Perdana Simpati Di Booth Telkomsel Matos). Jurnal Administrasi Bisnis (JAB). 35 (1) : 151.

\section{Sumber Internet :}

Jalan Tikus. 2018. Aplikasi My Telkomsel. https://jalantikus.com/tips/aplikasi-my-telkomsel/. (Diakses pada tanggal 08 Juni 2018)

Pikiran Rakyat. 2017. Ini Keuntungan Menggunakan Paket Internet Simpati 4G LTE. http://www.pikiranrakyat.com/ekonomi/2017/09/28/ini-keuntungan-menggunakan-paket-internet-simpati-4g-lte-410358. (Diakses pada tanggal 02 Februari 2018).

Top Brand Award. 2018. Top Brand Award Indek 2018 Fase 1. http://www.topbrand-award.com/top-brandsurvey/survey-result/top_brand_index_2018_fase_1. (Diakses pada tanggal 05 Mei 2018). 